Perspective

\section{Harem women}

\section{Perspective}

So Humanae Vitae was right: The removal of sexuality from its natural purpose of reproduction is pollution i.e., any activity not in synchrony with nature on the planet. This is now proven because non-reproductive sexuality has destroyed human "femaleness" on the planet. In nature, females are in charge and will only mate to reproduce as biochemically determined by pheromones (or pheromone equivalent mores for humans). But today, human females are no longer real females as in nature faithful to reproduction. Without such natural direction, American women are now "harem women"unmarriageable, anti-family, incapable of decent mothering, antisocial, selfish, traitorous to all femaleness, and unworthy of much more than being treated like the c-s-ing f-ers they are (You know it; I know it; they know it!), which is the most accurate and complete way to describe those who betray all womankind--and they will pull the "you are against women when you say those things". In addition, because they relentlessly hit on married men, they are flagrantly rejecting and disrespecting their sisterhood with all other (and married) women. Thus, American women are now the world's first community harem. The pollution due to feminism is much worse than a massive oil spill in the ocean. As my patient told me in the $80 \mathrm{~s}$, "American women are something--you can get a hand job, a blow job or a quick screw--it is as significant for our relationship as taking a leak." He was going to go back to Jamaica to get a decent woman to marry--as a new college assistant professor, he did not want an "over-used untrustworthy socalled partner who cannot be faithful."

1. Feminists are frauds when they themselves use against males the very discrimination about which they complain has been used against females (The same applies to all other victimhood wackos who turn into chauvinist intolerant bullies as they ironically complain about the same thing done against them). Feminists rarely really praise and support males, especially their boys. Almost ALWAYS with boys (and almost all males), feminists will have a question (meaning he could have been better), a doubt (meaning he was likely to be wrong), an alternative (meaning he did not know the best way), or an absolute snarl (meaning he was just being wrong as all males really are all the time). Feminists do not want to listen to males. Males are always wrong. Boys are now raised psychologically castrated by feminists. This why girls have done so well in school and all else, compared to boys in some subcultures wherein the women are haremfeminists who destroy the boys by anti-male-virtue sexism and destroy the men by oversexualizing them into numbed incompetence and irrelevancy. That trend is "feminism."

2. Feminists destroy the family when they hit on married men. In my youth, young women respected married women by never getting involved with a married man: "He belongs to her!" was the overt rule understood by all and almost universally followed. That a man is married is no longer respected as part of the female rights of his wife.

3. Feminists have adopted male sexuality incompetently--as one
Volume 6 Issue 6 - 2017

\author{
Samuel A Nigro M.D \\ Retired, Assistant Clinical Professor Psychiatry, Case Western \\ Reserve University School of Medicine, USA
}

Correspondence: Dr. Samuel A Nigro M.D., Retired,Assistant Clinical Professor Psychiatry, Case Western Reserve University School of Medicine, 2517 Guilford Road, Cleveland Heights, Ohio 44I I8, USA, Tel 216 932-0575, Email sam@docnigro.com

Received: May 01, 2016 | Published: February 06, 2017

hears young women complain of "rape" after placing themselves in flagrant copulation expected situations but then feel guilty needing, once sober, to deny consent and reject readily seen consequences not cared about when high or enjoying the excitement of a copulation expected situation. In a masturbatory culture with sexuality reduced to simple squirting and sliming any way every way, feminists cannot complain when they place themselves where and when it is expected and can easily happen.

4. Feminists have destroyed the prime dictionary meaning of female as "designating the sex that produces ova and bears offspring" (For male, it is "designating the sex that fertilizes the ovum and begets offspring."). Thus, the planetary and natural functioning of humans have been destroyed by feminists.

5. Feminists openly demean and dis-empower males beginning in grade schools as the special needs of boys (because of their innate higher activity levels) are punished rather than converted into intellectual pursuits.

6. Feminists consider "family" to be a problem rather than the natural traditional solution to incivility and lack of culture.

7. Feminists want the natural traditional paternalism accompanying male strength and power to be replaced by passive transfer of the same paternalistic power to women who do not have to realize thankfully or even gratefully believe what they have convinced men to do. This further destroys the family as males no longer exert virtue for their family as first identified in the Moynihan Report on the Negro Family in 1965 as black males have been rendered obsolete for everything by black feminists.

8. Feminists destroy the right to childhood by imposing adult sexuality and violence onto children so they do not learn positive life, sacrifice, virtue, love, humanity, peace, freedom and death without fear (the Catholic Mass Mantra).

9. Feminists have increased violence against women by ignoring the most common sites of such violence: lesbian households. 
10. Feminists have become a genital cult, as party to the gay cult, which has de-natured "sex" into a selfish masturbatory culture deserving mockery, instead of love based sacredness in marriage offering unity and reproduction in concert with Nature and Nature's God promoted by the Founders.

11. Feminists have destroyed marriage as the psycho-social pheromone for humans ever since we escaped from biological pheromones which rule in nature for the rest of the animal kingdom confining animals to sexual activity only between opposite sexed mature members of the same species at time of likely reproduction.

12. Feminists have become promoters of "evil is good" authorityobedience of Adolf Eichmann well proven by Stanley Milgrim.

13. Feminists are SELFISH SEXISTS and all the words imply.

14. To demand EQUALITY is a trap door. Think of the woman in the elevator who struck her NFL husband in a heated argument. An "I am a man too" equal proclamation. Of course, he decks her in a quick down and out and did not wail away like he would have if she were to be treated really as a "man". There is the other NFL guy in a bar and a pretty blond engaging in laughing then tense and hostile snarling, strikes him in the face with her closed fist--he decks her and all separate without his wailing away as if she were a man. Both gals proclaimed their womanhood after demonstrating their male-equal feminism. Both guys get penalized by the NFL who refuse to allow women to be men even when they act like men. Call it a violation of the Equal Misery Amendment as movies et al portray females as tough-as-men gals who do well fighting males--suggestible women imitate this but find the men do not crumble as on television. Then there are "fighting words" for men--perhaps women using those words should be treated equally as a man would be as a welcome to the real equality they claim to want.

15. Feminists, by abortion's subliminal psychological effects, reject "Life, Liberty and the Pursuit of Transcendentals" which means: no Judeo-Christianity $=$ no homemakers $=$ no childhood $=$ no manhood $=$ no virtue $=$ no culture $=$ LOSERS $!=$ TRASH .

16. The utopian unequal feminism of Sweden is an outrageous example of feminists getting special treatment as females so they can proclaim "equality" as the Swedish males do their universal Swed'anger--or Swedish "regretful making nice (the meaning of 'anger in Swedish)"-----calm, benign, selfrighteous, --it really comes down to "unapologetic cowardly making nice"---which the only things Swedes really do... (like not joining the Allies to shorten World War II by a year or more had they any manhood then too)--It is sort of their remaining version of Christianity. Just know that Sweden's "feminist equality" everywhere is an oxymoron--It will be that way unless feminists are REALLY TREATED LIKE MALES every where, every time, about every thing They will not like it.

By becoming: a "do not assert your full male virtue and unnecessary dad, an incompetent family man, a gay cult genital maniac, a drugusing uneducated unemployable parasite, and a criminal. That also was the celebrated "women's march" all over the world in January 2017, which actually had women doing what they claimed to be protesting. Isn't that just like a woman?

The results are protests and riots from the Losers (nee' Womens) March to Berkeley--ALL raging rioting protestors NEED Octavio Paz' "San Ildefonso nocturne":
Good, we wanted good: to set the world right. We didn't lack integrity: we lacked humility. What we wanted was not innocently wanted. Precepts and concepts, the arrogance of theologians, to beat with a cross, to institute with blood.... Some became secretaries to the secretary to the General Secretary of the Inferno. Rage became philosophy, its evil has covered the planet.

If you do not think this is true, check the Moynihan Report again and all that has happened to any group with feminists.

From my pamphlet: "What the Equal Rights Amendment Means to Men" of 1974:

Typically ignored are the following fundamental constructs of feminism:

Barbara Balogun (in Voices From Women's Liberation 1971): "I feel that the personal relationships of marriage must under go a revolution...the roles of male and female must be completely redefined-no, eliminated. I do not see this as possible in the present relationships of marriage...The only alternative, as I see it, is communal living...I also recognize that, conditions being what they are at the present time, most men feel so secure in their oppressive role that they will not give up their power willingly. Therefore, male-female communes will be impossible to establish. It may be that our only solution will be the dissolution of marrriage, with the foundation of all-female communes to eliminate the burdens placed on women."

Also in Voices From Women's Liberation, Linda Gordon states: "Families perpetuate themselves and their bad values by educating children to see them as the only models for adult life...The nuclear family must be destroyed, and the people must find better ways of living together."

On the book entitled The Second Sex published in 1971, Simone de Beauvoir describes a complete lack of satisfaction in motherhood and marriage: "The tragedy of marriage is not that it fails to assure women the promised happiness...but that it mutilates her; dooms her to repetition and routine...At twenty or therabouts mistress of a home, bound permanently to a man, a child in her arms, she stands with her life virtually finished forever. Real activities, real work, are the prerogative of her man: She has mere things to occupy her which are sometimes tiring but never fully satisfying."

Feminism has always been "haremfeminism" and most accurately seen as the "Women's Selfishness Movement"---and it is against Nature when compared to male/female relations for all creatures on the planet except the disordered. Finally, feminism is against Nature's God whose Lovelution Religion gave mankind, males and females, the transcendental distinctions and nature-based relationship patterns necessary for ultimate salutary human purposes of truth, oneness, good and beauty.

\section{Dred Scott, Wounded Knee, Fraud Press, Children-To-Be}

Four places in history.

Dred Scott, Wounded Knee, Fraud Press, Children-To-BeAt each place someone cried.

Dred Scott, Wounded Knee, Fraud Press, Children-To-BeAt each place someone died.

Dred Scott, Wounded Knee, Fraud Press, Children-To-BeFor America committed suicide.

At Dred Scott, Wounded Knee, Fraud Press and ChildrenTo-Be.

Do not call feminists "women" or "female." They are "haremfeminists" who should be treated equally as males in all things. 
"Gender" is meaningless since Oberforge v. Hodges which declared mental illnesses to be normal if part of one's "heart of liberty." They want equality--give it to them. No engagement rings which are the worst sexism ever for centuries. No traditional special considerations as for real women who know and love transcendence. No door openings. No soft ball pitching. No holding back after they hit you-treat them like the "men" they want to be. Always compete and do what you would do if they were men. Otherwise, in their supreme selfishness, they will walk all over you like you are an idiot.

\section{Acknowledgments}

None.

\section{Conflicts of interest}

None.

\section{Funding}

None. 